\title{
Neonatal exposure to estrogen differentially alters estrogen receptor $\alpha$ and $\beta$ mRNA expression in rat testis during postnatal development
}

\author{
M Tena-Sempere ${ }^{1}$, J Navarro ${ }^{1}$, L Pinilla ${ }^{1}$, L C González ${ }^{1}$, \\ I Huhtaniemi ${ }^{2}$ and E Aguilar $^{1}$ \\ ${ }^{1}$ Department of Physiology, University of Córdoba, 14004 Córdoba, Spain \\ ${ }^{2}$ Department of Physiology, University of Turku, 20520 Turku, Finland \\ (Requests for offprints should be addressed to M Tena-Sempere, Department of Physiology, Faculty of Medicine, University of Córdoba, \\ Avda Menéndez Pidal s/n, 14004 Córdoba, Spain; Email: fi1tesem@lucano.uco.es)
}

\begin{abstract}
The biological actions of estrogens on target cells are mediated by two nuclear receptors: the estrogen receptor (ER) $\alpha$ and the recently characterized ER $\beta$. In the male rat, the physiological role of estrogens involves multiple actions, from masculinization of brain areas related to reproductive function and sexual behavior to regulation of testicular development and function. Paradoxically, however, administration of high doses of estrogen during the critical period of neonatal differentiation results in an array of defects in the reproductive axis that permanently disrupt male fertility. The focus of this study was to characterize the effects and mechanism(s) of action of neonatal estrogenization on the pattern of testicular ER $\alpha$ and $\beta$ gene expression during postnatal development. To this end, groups of male rats were treated at day 1 of age with estradiol benzoate $(500 \mu \mathrm{g} / \mathrm{rat})$, and testicular ER $\alpha$ and ER $\beta$ mRNA levels were assayed by semi-quantitative RT-PCR from the neonatal period until puberty (days 1-45 of age). Furthermore, the expression of androgen receptor (AR) mRNA was evaluated, given the partially overlapping pattern of tissue distribution of $\mathrm{ER} \alpha, \mathrm{ER} \beta$
\end{abstract}

and AR messages in the developing rat testis. In addition, potential mechanisms for neonatal estrogen action were explored. Thus, to discriminate between direct effects and indirect actions through estrogen-induced suppression of serum gonadotropins, the effects of neonatal estrogenization were compared with those induced by blockade of gonadotropin secretion with a potent LHRH antagonist in the neonatal period. Our results indicate that neonatal exposure to estrogen differentially alters testicular expression of $\alpha$ and $\beta$ ER messages: ER $\alpha$ mRNA levels, as well as those of AR, were significantly decreased, whereas relative and total expression levels of ER $\beta$ mRNA increased during postnatal/prepubertal development after neonatal estrogen exposure, a phenomenon that was not mimicked by LHRH antagonist treatment. It is concluded that the effect of estrogen on the expression levels of ER $\alpha$ and $\beta$ mRNAs probably involves a direct action on the developing testis, and cannot be attributed to estrogeninduced suppression of gonadotropin secretion during the neonatal period.

Journal of Endocrinology (2000) 165, 345-357

\section{Introduction}

Despite the classical contention that estrogen is the female hormone, compelling evidence indicates a pivotal role of estrogen in the regulation of development and function of several systems in the male. In mammals, these actions include permanent masculinization of brain structures involved in neuroendocrine control of gonadal function and reproductive behavior (MacLusky \& Naftolin 1981, Arnold \& Gorski 1984), regulation of differentiation and function of Leydig cells within the testis (Brinkmann et al. 1980, Abney \& Myers 1991), modulation of luminal fluid resorption in the epididymis (Hess et al. 1997), and control of follicle-stimulating hormone (FSH) secretion (Sharpe
1998), as well as direct effects on bone and the cardiovascular system (Nilsson et al. 1998, Sharpe 1998).

The biological actions of estrogen are targeted through interaction with a specific intranuclear receptor, termed the estrogen receptor (ER). Two different subtypes of ER have been identified so far: the classical ER (renamed ER $\alpha$ ), and the recently characterized ER $\beta$ (Green et al. 1986, Greene et al. 1986, Koike et al. 1987, Kuiper et al. 1996, Tremblay et al. 1997). Interestingly, $\alpha$ and $\beta$ forms of ER have been shown to possess different binding affinities for a variety of estrogenic compounds (Kuiper et al. 1997), distinct patterns of tissue distribution (Fisher et al. 1997, Shughrue et al. 1997, Mitchner et al. 1998, Österlund et al. 1998, Saunders et al. 1998, Sar \& Welsch 1999), as well as 
different transactivation activities on estrogen-regulated gene constructs (Paech et al. 1997, Pennie et al. 1998). Indeed, identification of the novel ER $\beta$ has attracted considerable attention as it may provide the molecular basis for the complexity and plasticity of biological actions of naturally occurring and synthetic estrogenic compounds (Kuiper et al. 1998).

In male rodents, it is well established that exposure to supra-physiological doses of estrogens during the critical period of neonatal differentiation results in an array of permanent reproductive defects, which include atrophy of testes and sexual accessory glands (Kincl et al. 1965, Brown-Grant et al. 1975, Aguilar et al. 1984, Newbold \& McLachlan 1985, Naslund \& Coffey 1986), impaired maturation of germ, Sertoli and Leydig cells (Gaytán \& Aguilar 1986, Gaytan et al. 1986, Pinilla et al. 1992, Sharpe et al. 1998), altered luteinizing hormone (LH) secretion (Aguilar et al. 1984, Pinilla et al. 1995), and inappropriate puberty onset (Brown-Grant et al. 1975, Bellido et al. 1985). Disruption of reproductive function by neonatal estrogenization is probably a multifaceted phenomenon, and complete elucidation of the mechanism(s) involved is still pending. Concerning testicular damage, experimental evidence has emphasized the role of estrogen-induced decrease in gonadotropin secretion neonatally (Bellido et al. 1990), although a direct action of estrogens on the developing male gonad has been suggested recently (Sharpe et al. 1998). Worthy of note, little attention has been paid to molecular events in the rodent testis after neonatal estrogenization, although analogous studies have been carried out on the prostate and uterus (Pylkkanen et al. 1993, Prins \& Birch 1995, Zheng \& Hendry 1997 , Prins et al. 1998). Interestingly, complete characterization of the deleterious effects and the mechanism(s) of action of exogenous estrogens, administered during the fetal/ neonatal period, on differentiation and function of reproductive organs has become relevant in the face of potential hazardous effects of environmental xenoestrogens on male fertility (for a review see Toppari et al. 1996).

In the present study, we aimed at evaluating the effect of neonatal estrogen exposure on the pattern of ER $\alpha$ and ER $\beta$ mRNA expression in rat testis during development from birth to puberty. Further, the impact of neonatal estrogenization on the pattern of expression of androgen receptor (AR) mRNA was analyzed, given the partially overlapping pattern of cellular distribution of $\operatorname{ER} \alpha, \mathrm{ER} \beta$ and AR messages in developing rat testis (Bremner et al. 1995, Fisher et al. 1997, Saunders et al. 1998, Van Pelt et al. 1999). In addition, we sought potential mechanisms underlying the effects of neonatal administration of estrogen on testicular ER $\alpha$ and ER $\beta$ mRNA expression. Thus, considering that the developing testis has been suggested as a potential target for estrogen action (Fisher et al. 1997, Saunders et al. 1998, Sharpe et al. 1998, Van Pelt et al. 1999), we explored the possibility of a direct action of estrogen at the testicular level by comparing the effects of neonatal estrogenization with those induced by the blockade of gonadotropin secretion through administration of a potent LH-releasing hormone (LHRH) antagonist (LHRH-ANT) neonatally.

\section{Materials and Methods}

\section{Animals and drugs}

Male Wistar rats bred in the vivarium of our institution were used. The day the litters were born was considered day 1 of life. At this time, the litter size was adjusted to eight rats per dam. The animals were maintained under controlled conditions of light ( $14 \mathrm{~h}$ of light; lights on at $0700 \mathrm{~h}$ ) and temperature $\left(22^{\circ} \mathrm{C}\right)$. The animals were weaned at 21 days of age and housed thereafter in groups of five per cage, with free access to pelleted food and tap water.

Estradiol benzoate (EB) was obtained from Sigma (St Louis, MO, USA), and the LHRH-ANT Org 30276 (Ac-D-pClPhe-D-pClPhe-D-Trp-Ser-Tyr-D-Arg-Leu-ArgPro-D-Ala- $\mathrm{NH}_{2} \mathrm{CH}_{3} \mathrm{COOH}$ ) was generously supplied by Organon (Oss, Netherlands). For administration, EB was dissolved in olive oil and the LHRH-ANT in physiological saline $(0.9 \% \mathrm{NaCl})$.

\section{Experimental designs}

The effects of neonatal exposure to estrogen on the pattern of ER $\alpha$, ER $\beta$ and AR mRNA expression during postnatal testicular development were monitored in Experiment 1. To this end, 1-day-old male rats were injected s.c. with a single dose of EB $(500 \mu \mathrm{g} / \mathrm{rat})$; this protocol was selected on the basis of our previous studies as it was found to be the most effective in inducing complete estrogenization in the male rat (Aguilar et al. 1984, Bellido et al. 1985, 1990, Gaytan \& Aguilar 1986, Gaytan et al. 1986, Pinilla et al. 1992, 1995). Vehicle (oil)-injected rats served as controls. Groups of animals were sequentially killed on day 1 (within the first $24 \mathrm{~h}$ of postnatal life, i.e. before EB administration), and on days 5, 10, 15, 20, 30 and 45 of age. In Experiment 2, the potential mechanism(s) involved in the effects of neonatal estrogenization on the pattern of testicular ER $\alpha$, ER $\beta$ and AR mRNA expression was evaluated. Since the effects of neonatal exposure to estrogen on the reproductive axis are mediated, at least partially, by postnatal suppression of gonadotropins (Bellido et al. 1990), expression levels of ER $\alpha$, ER $\beta$ and AR mRNAs were evaluated in testes of rats treated neonatally with LHRH-ANT, and compared with those of neonatally estrogenized males. Male rats were injected s.c. with LHRH-ANT (5 mg/kg body weight) on days 1 , $4,7,10,13$ and 15 of age, as described previously (Pinilla et al. 1994). For comparative analysis, two age-points were selected for tissue sampling: day 15 ( $4 \mathrm{~h}$ after the last 
LHRH-ANT injection) and day 45. In all experiments, trunk blood, testes, and ventral prostates were taken, and the weights of the organs recorded. Sera were separated from blood samples and stored at $-20{ }^{\circ} \mathrm{C}$ until used for hormone measurements. After removal, the testes were immediately frozen in liquid nitrogen and stored at $-70{ }^{\circ} \mathrm{C}$ until used for RNA analyses. All the experimental procedures were approved by the Córdoba University Committee on Laboratory Animal Care, and were conducted in accordance with the European Union Normative for care and use of experimental animals.

\section{$R N A$ analysis by semi-quantitative RT-PCR}

RT-PCR, optimized for semi-quantitative detection (see below), was used to analyze relative expression levels of ER $\alpha$, ER $\beta$ and AR mRNAs in the different experimental groups. Total RNA was isolated from testicular samples using the single-step, acid guanidinium thiocyanatephenol-chloroform extraction method, as described previously (Chomczynski \& Sacchi 1987). For amplification of the target genes, the following primer pairs were used: ER $\alpha$-sense (nt 472-492; 5'-AAT TCT GAC AAT CGA CGC CAG-3') and ER $\alpha$-as (nt 816-794; 5'-GTG CTT CAA CAT TCT CCC TCC TC-3'), for amplification of a 344-bp fragment of rat ER $\alpha$ cDNA; ER $\beta$-sense (nt 38-58; 5'-TTC CCG GCA GCA CCA GTA ACC-3') and ER $\beta$-as (nt 299-279; 5'-TCC CTC TTT GCG TTT GGA CTA-3'), for amplification of a 262-bp fragment of rat ER $\beta$ cDNA; and AR-sense (nt 1623-1645; 5'-CCC ATC GAC TAT TAC TTC CCA CC- ${ }^{\prime}$ ) and AR-as (nt 1913-1891; 5'-TTC TCC TTC TTC CTG TAG TTT GA-3'), for amplification of a 291-bp fragment of AR cDNA. The reported sets of primers were selected based on previous references (Shan et al. 1995, Kuiper et al. 1997), and synthesized according to the published cDNA sequences of rat ER $\alpha$ (Koike et al. 1987), ER $\beta$ (Kuiper et al. 1996) and AR (Chang et al. 1988). In addition, to provide an appropriate internal control, coamplification of a 290-bp fragment of the L19 ribosomal protein mRNA was carried out in each sample using the primer pair: L19-sense (nt 91-110; 5'-GAA ATC GCC AAT GCC AAC TC-3') and L19-as (nt 380-361; 5'-ACC TTC AGG TAC AGG CTG TG-3'), generated according to the rat L19 ribosomal protein cDNA (Chang et al. 1987).

For amplification of the target genes, RT and PCR were run in two separate steps. Furthermore, to enable appropriate amplification in the exponential phase for each target, PCR amplification of ER $\alpha$, ER $\beta$, AR and L19 ribosomal protein transcripts was carried out in separate reactions with a different number of cycles (see below), but using similar amounts of the corresponding cDNA templates, generated in single RT reactions, as described elsewhere (Santana et al. 1996, Tena-Sempere et al. 1999). Briefly, equal amounts of total testicular RNA $(4 \mu \mathrm{g})$ were heat denatured and reverse transcribed by incubation at
$42{ }^{\circ} \mathrm{C}$ for 90 min with $12.5 \mathrm{U}$ avian myeloblastosis virus (AMV) RT (Promega, Madison, WI, USA), 20 U ribonuclease inhibitor RNasin (Promega), $200 \mathrm{nM}$ deoxyNTP mixture, and $200 \mathrm{pmol}$ random hexamer primers (Promega), in a final volume of $30 \mu \mathrm{l} 1 \times$ AMV-RT buffer. The reactions were terminated by heating at $97^{\circ} \mathrm{C}$ for $5 \mathrm{~min}$ and cooling on ice, followed by dilution of the RT cDNA samples with nuclease-free $\mathrm{H}_{2} \mathrm{O}$ (final volume $60 \mu \mathrm{l}$ ). For semi-quantitative PCR, $10 \mu \mathrm{l}$ aliquots of the cDNA samples (equivalent to $650 \mathrm{ng}$ total RNA input) were amplified in $50 \mu \mathrm{l} 1 \times$ PCR buffer in the presence of 2.5 U Taq-DNA polymerase (Promega), $200 \mathrm{nM}$ deoxyNTP mixture, and the appropriate primer pairs (1 $\mathrm{nM}$ of each primer; see above). PCR reactions consisted of a first denaturing cycle at $97^{\circ} \mathrm{C}$ for $5 \mathrm{~min}$, followed by a variable number of cycles of amplification defined by denaturation at $96{ }^{\circ} \mathrm{C}$ for $1.5 \mathrm{~min}$, annealing at $55^{\circ} \mathrm{C}$ for $1.5 \mathrm{~min}$, and extension at $72{ }^{\circ} \mathrm{C}$ for $3 \mathrm{~min}$. A final extension cycle of $72{ }^{\circ} \mathrm{C}$ for $15 \mathrm{~min}$ was included. The number of cycles was optimized to ensure amplification in the exponential phase of PCR. Different number of cycles were tested for ER $\alpha$, ER $\beta$, AR (ranging between 25 and 45) and L19 ribosomal protein (ranging between 14 and 30) and 33, 37,35 and 20 cycles, respectively, were chosen for further analysis (see Results).

The generated cDNA fragments were resolved in 1.5\% agarose gels containing ethidium bromide $(0.1 \mu \mathrm{g} / \mathrm{ml})$, and their molecular sizes determined by comparison with size markers (PCR 50-bp Step Ladder, Promega) run together with the cDNA products (1-D Manager software, TDI Ltd, Madrid, Spain). Specificity of PCR products was confirmed by Southern hybridization, using radiolabeled nested oligonucleotide primers (data not shown), as described elsewhere (Kuiper et al. 1997, Tena-Sempere et al. 1999). For quantitative evaluation of RT-PCR signals, electrophoretically separated cDNA fragments were photographed using 667 Polaroid films (Polaroid, Cambridge, MA, USA), and the images were digitized using an IBM flatbed scanner. Absolute optical densities (ODs) for each PCR product were obtained by densitometric scanning of the digital signals using an image analysis system (1-D Manager, TDI Ltd), and the values for the specific target genes (ER $\alpha, E R \beta$ and AR) were normalized with respect to those of L19 ribosomal protein to express arbitrary units of relative abundance of the specific messages (relative expression). In addition, as neonatal administration of EB and LHRH-ANT induced permanent atrophy of testes, semi-quantitative presentation of densitometric values after correction for testicular weight was also included. This gives a reliable estimate of total level of expression of each message per testis (total expression). To ensure that equal inputs of RNA were added to RT-PCR reactions, only samples yielding roughly similar OD values for L19 bands were considered for further analysis. In addition, to minimize potential RT-PCR artifacts due to inherent reaction variability, all 
data-points were repeated, for each target gene, at least three times using independent RNA samples. Finally, primer pairs were synthesized according to previous references (Shan et al. 1995, Kuiper et al. 1997), designed to span over intronic sequences to exclude potential amplification of contaminant genomic DNA. Furthermore, in all assays, liquid controls and reactions without RT were included, yielding negative amplification (data not shown).

\section{Hormone measurements}

Serum LH levels were measured using a supersensitive, time-resolved, immunofluorometric assay (IFMA-Delfia, Wallac Oy, Turku, Finland), as described elsewhere (Haavisto et al. 1993). The results were expressed in terms of the reference preparation LH-RP-2 (National Institute of Diabetes, Digestive and Kidney Diseases (NIDDK), Bethesda, MD, USA); the sensitivity of the assay was $0.75 \mathrm{pg} /$ tube, the intraassay coefficient of variation (CV) was $7 \%$, and the interassay CV 10\%. Serum FSH levels were assayed by a novel time-resolved immunofluorometric assay, based on the Delfia principle (Hakola et al. 1999), with minor modifications. A new pair of antibodies was used: an anti-human FSH $\beta$ monoclonal antibody (FSH 56 A) as the capture antibody, and a polyclonal anti-human $\alpha$-subunit antibody (R93-2705) as the signal antibody. Both were kindly donated by Dr W Schoonen (Organon). The results were expressed in terms of the reference preparation FSH-RP-2 (NIDDK); the analytical sensitivity of the assay was $203 \mathrm{pg} / \mathrm{tube}$, the intraassay $\mathrm{CV}$ was $<4 \%$, and the interassay CV was $5 \cdot 5 \%$. Serum testosterone levels were measured by RIA, after diethyl ether extraction of the samples, using ${ }^{125}$ I-labeled testosterone (Orion-Farmos Diagnostica, Turku, Finland) as tracer and testosterone antiserum kindly donated by Dr R Vihko (Department of Clinical Chemistry, Oulu University, Finland).

\section{Statistics}

Semi-quantitative data are expressed as means \pm S.E.M. from three to five independent observations. Statistically significant differences between groups were determined by one-way ANOVA, followed by Tukey's test. $P<0 \cdot 05$ was considered statistically significant.

\section{Results}

\section{Endocrine profiles (Fig. 1)}

To evaluate the endocrine background for testicular expression of ER $\alpha$, ER $\beta$ and AR mRNAs, serum FSH, LH and testosterone levels were measured, and testicular weights were recorded, in the experimental groups.
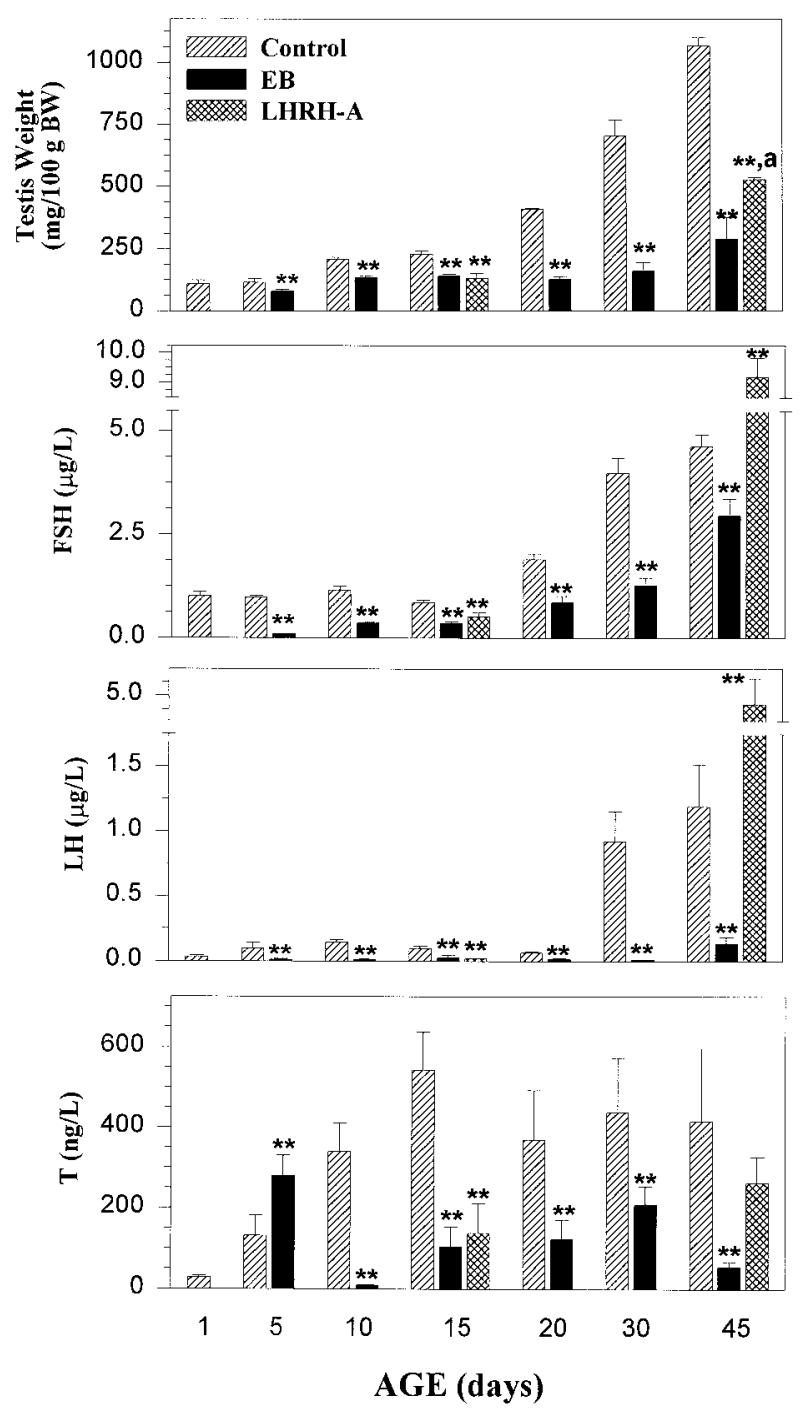

Figure 1 Testicular weights (upper panel), and serum FSH, LH and testosterone $(\mathrm{T})$ levels (middle and lower panels) in the experimental groups indicated, at different time-points along the developmental time-frame between the neonatal period (day 1 of age) and puberty (day 45 of age). The experimental groups were: control rats, rats treated neonatally with $\mathrm{EB}(500 \mu \mathrm{g} / \mathrm{rat}$, on day 1$)$, and rats treated with LHRH-ANT (LHRH-A) during the neonatal period ( $5 \mathrm{mg} / \mathrm{kg}$ every $72 \mathrm{~h}$, from days 1 to 15 ). Values are given as means \pm S.E.M. $\left(n=4-8\right.$ samples/group). ${ }^{*} P<0 \cdot 01$ vs values from corresponding controls; $\mathrm{a}=P<0.01$ vs values from corresponding EB-injected groups (ANOVA followed by Tukey's test).

Control animals showed a gradual increase of testicular weight along the study period (from days 1 to 45 of age). In this group, low levels of FSH and $\mathrm{LH}$ were detected from days 1 to 20, followed by a sharp elevation between days 20 and 30 of age. Serum testosterone values were low at birth, increased gradually from days 1 to 15 of age, and remained similar thereafter. However, a further increase in 
serum testosterone levels took place in paired, 75-day-old male rats (1800.6 $\pm 391.5 \mathrm{ng} / \mathrm{l}$; personal observation). In keeping with previous references (Kincl et al. 1965, Brown-Grant et al. 1975, Bellido et al. 1985, 1990, Pinilla et al. 1992, 1995), neonatal administration of $\mathrm{EB}(500 \mu \mathrm{g} /$ rat; day 1) resulted in permanent atrophy of testes, and significantly decreased serum FSH, LH and testosterone levels during the study period. Finally, neonatal administration of LHRH-ANT ( $5 \mathrm{mg} / \mathrm{kg}$ every $72 \mathrm{~h}$; days 1-15) induced a significant reduction in testicular weight on days 15 and 45 of age, as well as significant decreases in serum FSH, LH and testosterone values on day 15 of age. However, in line with previous reports (Huhtaniemi et al. 1986, Pinilla et al. 1994), serum testosterone concentrations were normal, and FSH and LH levels were increased over control values in 45-day-old animals neonatally treated with LHRH-ANT. Based on previous references, such a rebound in serum gonadotropin levels was probably initiated around day 25 of age (Pinilla et al. 1994).

\section{Optimization of semi-quantitative RT-PCR assays}

RT-PCR assays were optimized for semi-quantitative analysis of ER $\alpha$, ER $\beta, A R$ and L19 ribosomal protein mRNA expression. To obtain optimal conditions for amplification, i.e. in the exponential phase of PCR, different numbers of PCR cycles were tested for each message. As shown in Fig. 2, plotting of intensity of PCR signals (as expressed by absolute OD values) against the number of amplification cycles revealed a strong linear relationship between cycles 28 and 36 in the case of ER $\alpha$ (correlation coefficient $r^{2}=0 \cdot 9601$ ), cycles 30 and 38 in the case of ER $\beta\left(r^{2}=0 \cdot 9639\right)$, cycles 30 and 36 in the case of AR $\left(r^{2}=0 \cdot 9761\right)$, and cycles 14 and 23 in the case of L19 ribosomal protein $\left(r^{2}=0.9980\right)$. For this reason, PCR amplification of ER $\alpha$, ER $\beta$, AR and L19 ribosomal protein transcripts was carried out in separate reactions, using 33, 37, 35 and 20 amplification cycles respectively. The validity of the above RT-PCR assays for semiquantitative evaluation is supported by the following facts. First, single RT reactions using random hexamers were carried out for each sample, and similar amounts of generated cDNA (equivalent to an approximate input of 650 ng total RNA per sample) were used for further PCR amplification of each target gene. Secondly, only samples yielding similar OD values for L19 ribosomal protein transcripts were considered for analysis and, for semiquantitative presentation of data, expression values of specific target genes (ER $\alpha$, ER $\beta$ and AR) were normalized with respect to those of L19 ribosomal protein. Thirdly, all data-points were repeated, for each target gene, at least three times using independent RNA samples, thus avoiding potential RT-PCR artifacts due to inherent reaction variability. Finally, when the selected RT-PCR conditions were tested with increasing amounts of total RNA, a linear relationship between intensity of PCR signals and amount of starting RNA was found (Fig. 3).

\section{Testicular expression of ER $\alpha, E R \beta$ and $A R m R N A$ s in neonatally estrogenized rats}

Testicular expression of ER $\alpha$, ER $\beta$ and AR mRNAs was monitored in control and neonatally estrogenized animals throughout postnatal development by means of semiquantitative RT-PCR. Representative expression patterns of ER $\alpha$, ER $\beta$, AR and L19 mRNAs at different age-points from the neonatal period until puberty (days $1-45$ of age) are presented in Figs 4 and 5. A summary of semi-quantitative data on the steady-state $\operatorname{ER} \alpha, \operatorname{ER} \beta$ and AR mRNA levels throughout the study period is shown in Fig. 6. For clear presentation of data on relative expression (Fig. 6, left panels), the level of each specific message (ER $\alpha$, ER $\beta$ and AR) on day 1 of age was taken as $100 \%$ and the other values were normalized accordingly, thus allowing a semi-quantitative comparison between different time-points. In control animals, high levels of expression of ER $\alpha$, ER $\beta$ and AR mRNAs were detected in testes from neonatal-infantile rats. In the case of ER $\alpha$ and AR messages, a moderate decrease in the level of relative expression was observed from days 10 to 15 of age onwards, the values in 45-day-old rats being, respectively, between 60 and $65 \%$ and 70 and $75 \%$ of maximum levels in the infantile period. In contrast, a sharp decrease in the relative level of expression of ER $\beta$ mRNA was noted between days 15 and 20 of age. From this time-point onwards, ER $\beta$ mRNA levels remained low, ranging between 5 and $15 \%$ of maximum values of the neonatal period. Neonatal estrogenization profoundly altered the pattern of testicular expression of ER $\alpha, E R \beta$ and AR mRNAs throughout the study period. Both relative levels and total expression of ER $\alpha$ and AR mRNAs decreased in testes from rats neonatally treated with estrogen; the reduction in relative mRNA levels of $\mathrm{ER} \alpha$ and AR was statistically significant from day 15 onwards, but from days 5-10 onwards when considered in terms of total expression per testis. On the contrary, neonatal exposure to estrogen induced a marked increase in both relative levels and total expression of ER $\beta$ mRNA. This increase was statistically significant at all age-points studied.

\section{Testicular expression of ER $\alpha, E R \beta$ and $A R m R N A$ s in neonatally LHRH-ANT-treated rats}

Representative expression patterns of $\operatorname{ER} \alpha, \operatorname{ER} \beta, A R$ and L19 mRNAs in testes from 15- and 45-day-old rats treated neonatally with LHRH-ANT are shown in Fig. 5. In addition, compilation of semi-quantitative data on the steady-state levels of these messages is included in Fig. 6. Administration of LHRH-ANT during the neonatal 

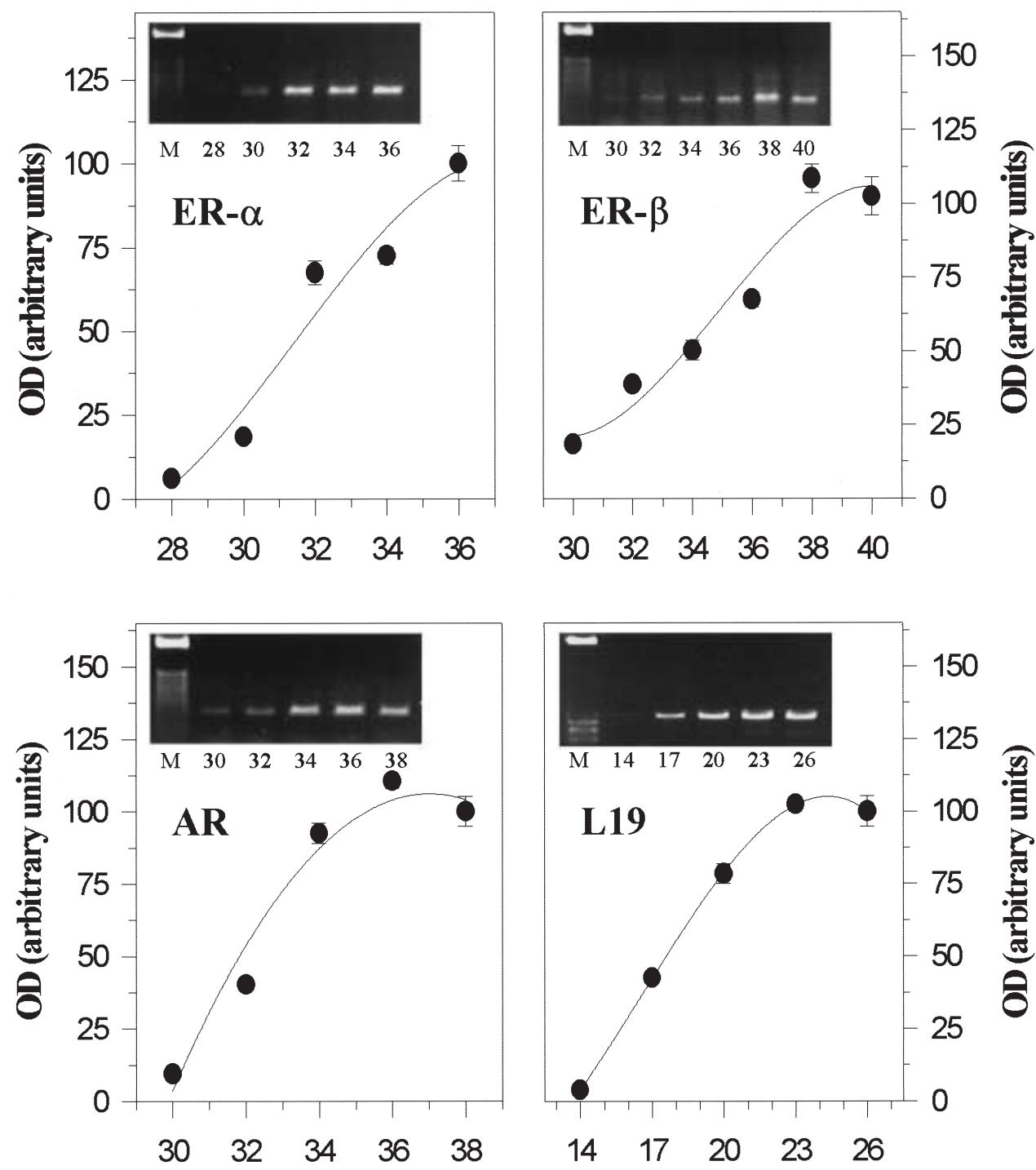

\section{Cycles ( $\left.\mathbf{n}^{0}\right)$}

Figure 2 Optimization of RT-PCR conditions for semi-quantitative determination of target mRNAs. For amplification in the exponential phase of PCR, different numbers of cycles were tested for each message. Quantitative analysis of the cycle dependency for the generated PCR signals revealed a strong linear relationship between cycles 28 and 36 in the case of ER $\alpha$ (correlation coefficient $r^{2}=0.9601$ ), cycles 30 and 38 in the case of ER $\beta\left(r^{2}=0.9639\right)$, cycles 30 and 36 in the case of AR $\left(r^{2}=0.9761\right)$, and cycles 14 and 23 in the case of L19 ribosomal protein $\left(r^{2}=0 \cdot 9980\right)$. Optimization of RT-PCR conditions was carried out using total RNA from control, 10-day-old rat testis. Values are given as means \pm S.D. of two independent determinations. A representative ethidium bromide-stained gel electrophoresis of the DNA products generated for each target is presented in the insets.

period failed to significantly alter the pattern of relative expression of ER $\alpha, \mathrm{ER} \beta$ and $\mathrm{AR}$ mRNAs in testes from 15-day-old rats, and only a slight increase, which was not significant, of relative expression levels of ER $\beta$ mRNA was apparent at this age-point. In addition, a significant decrease in terms of total expression was detected for ER $\alpha$. On day 45 postpartum, relative levels as well as total expression per testis of ER $\alpha$ and AR mRNAs were significantly decreased in animals neonatally treated with LHRH-ANT, whereas those of ER $\beta$ were at the 

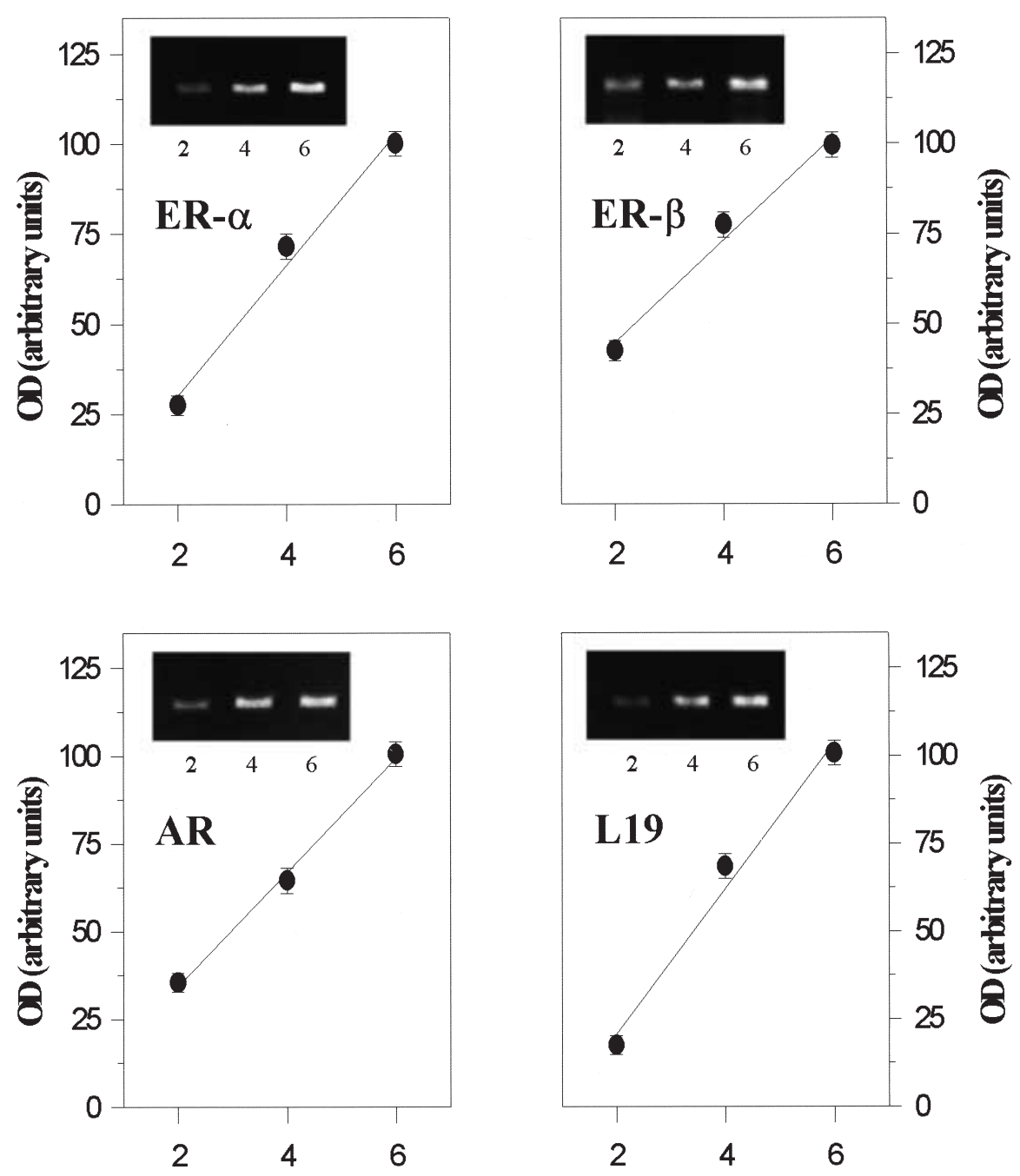

\section{Total RNA $(\mu \mathrm{g})$}

Figure 3 Dose dependency of the intensity of PCR signals. Increasing amounts of total RNA from control, 10-day-old rat testis were amplified by RT-PCR, using conditions selected for analysis of experimental samples (see Results). Quantitative analysis revealed a strong linear relationship between the amount of starting RNA and the intensity of the generated PCR signals, for each target message, under the selected conditions. Values are given as means \pm S.D. of two independent determinations. A representative ethidium bromide-stained gel electrophoresis of the DNA products for each target is presented in the insets.

limit of detection and not significantly different from their respective controls.

\section{Discussion}

To our knowledge, this is the first study to report the effects of neonatal exposure to estrogen on the expression of ER $\alpha$ and ER $\beta$ mRNAs in rat testis during postnatal/ prepubertal development. In this sense, although alterations in testicular morphology and function after neonatal exposure to estrogenic compounds have been well characterized (as examples see Gaytan \& Aguilar 1986, Gaytan et al. 1986, Tena-Sempere et al. 1993, Sharpe et al. 1998), little attention has been paid to molecular events in the rat testis after neonatal estrogenization. Several reasons prompted us to look for changes in the level of testicular expression of ER $\alpha$ and $\beta$ genes in this experimental model. First, the presence of $\mathrm{ER} \alpha$ and $\mathrm{ER} \beta$ in the developing testis has been well documented (Fisher et al. 


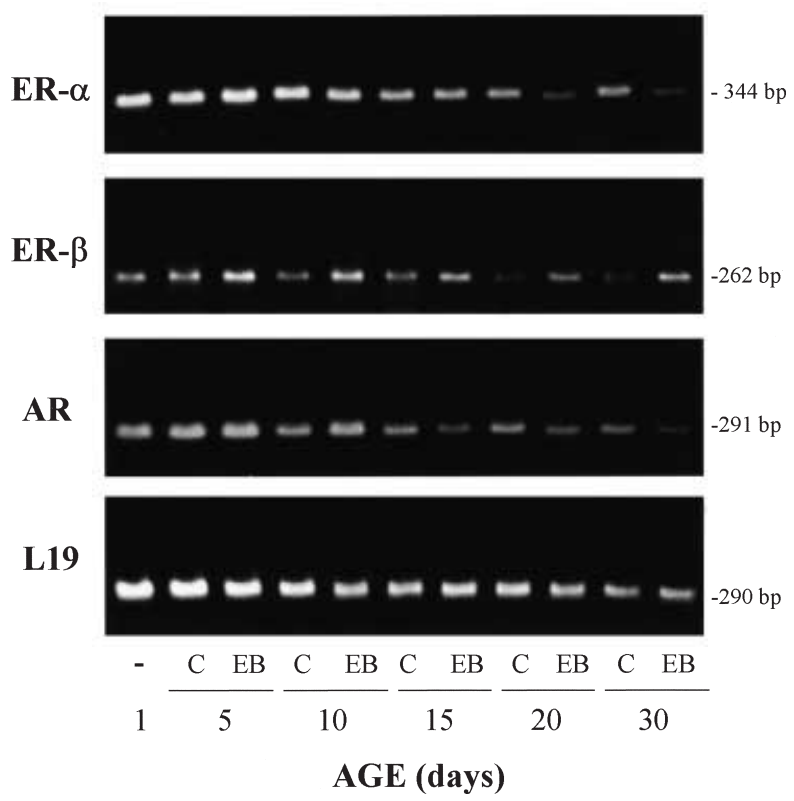

Figure 4 Representative ethidium bromide-stained gel electrophoresis of ER $\alpha, E R \quad \beta, A R$ and L19 cDNA fragments amplified by RT-PCR, using conditions selected for semiquantitative analysis. Assessment of the level of expression of the target genes was carried out from total testicular RNA samples of control (C) and neonatally estrogenized (EB) rats, at different time-points between days 1 and 30 of age. An additional age-point (day 45) is presented in Fig. 5. The sizes of the generated products were calculated by comparison with the mobility of size markers (PCR 50-bp Step Ladder; data not shown), and are indicated on the right.

1997, Saunders et al. 1998, Van Pelt et al. 1999), yet little was known about the homologous regulation of their expression at the mRNA level. Secondly, the molecular phenotype and mechanism(s) of testicular damage in the neonatally estrogenized rat remained to be fully characterized, and no attempt had been made to evaluate the potential contribution of changes in the pattern of expression of ER subtypes. In addition, identification of specific responses in terms of ER $\beta$ gene expression may help to elucidate its role, if any, in testicular development and function. In this sense, the widespread expression of ER $\beta$ in the male gonad, as well as its distinct pattern of cellular distribution from ER $\alpha$ (Fisher et al. 1997, Saunders et al. 1998, Van Pelt et al. 1999), strongly suggested a specific role of the $\beta$ form of ER in the regulation of testicular function. However, as reported recently (Krege et al. 1998), targeted disruption of ER $\beta$ gene failed to cause overt abnormalities in the reproductive tract, and neither did it impair male fertility. This is in contrast to the reproductive phenotype of knockout mice lacking the genes encoding ER $\alpha$ (Eddy et al. 1996) or aromatase (Robertson et al. 1999). The possibility remains, however, that although not absolutely essential for reproduction in the male, the $\beta$ form of ER may play a role in the fine-tuning of estrogen actions on testicular function. Interestingly, redundant regulatory pathways seem to operate within the testis to ensure fertility; as an example, the lack of biological actions of FSH, despite its wellproven role in the regulation of spermatogenesis, is associated with partially preserved male fertility, in both humans and rodents (Kumar et al. 1997, Tapanainen et al. 1997).

In our study, assessment of the level of expression of ER $\alpha$ and ER $\beta$ mRNAs was carried out by means of RT-PCR, optimized for semi-quantitative detection. Due to its high sensitivity and the ability to detect alternatively spliced transcripts, this method has become widely used for the analysis of ER $\beta$ mRNA expression in a variety of tissues, including the testis (for examples see Kuiper et al. 1997, Karolczak \& Beyer 1998, Petersen et al. 1998). In our approach, the reliability of semi-quantitative results is supported by (i) the selection, for each target gene, of amplification conditions in the exponential phase of PCR (Fig. 2), (ii) the repetitive observation of results for different RNA samples within the same experimental group, (iii) the use of an appropriate internal control and (iv) the positive linear correlation between RNA input and intensity of signal, using the selected RT-PCR conditions (Fig. 3). Semi-quantitative comparison was carried out in terms of relative mRNA levels and total expression per testis (i.e. after correction of densitometric values for testicular weight). The former gives an estimate of the relative abundance of each specific message, whereas the latter provides information on their total level of expression per gonad. This is relevant considering that neonatal administration of EB and LHRH-ANT induced a permanent reduction in testicular weight during the study period (Fig. 1).

Semi-quantitative evaluation by RT-PCR revealed that testicular expression of ER $\alpha$ and ER $\beta$ mRNAs is imprinted by neonatal exposure to estrogen in a strikingly opposite manner. Overall, relative levels and total expression of ER $\alpha$ mRNA were decreased in neonatally estrogenized rats during postnatal/prepubertal testicular development. On the contrary, testicular ER $\beta$ expression, in terms of both relative levels and total RNA expression, was increased in this animal model during the developmental time-frame studied. Moreover, neonatal estrogenization differentially altered the pattern of testicular expression of ER $\beta$ and AR mRNAs, as an overall reduction was observed in the relative levels and total RNA expression of AR, despite the fact that expression of both genes shares, at least partially, the pattern of cellular distribution within the testis (Bremner et al. 1995, Saunders et al. 1998, Van Pelt et al. 1999).

The mechanism(s) of action of neonatal estrogen on the developing testis was approached by comparing its effects with those induced by the blockade of gonadotropin secretion through administration of a potent LHRH-ANT during the neonatal period. This comparative setting has 


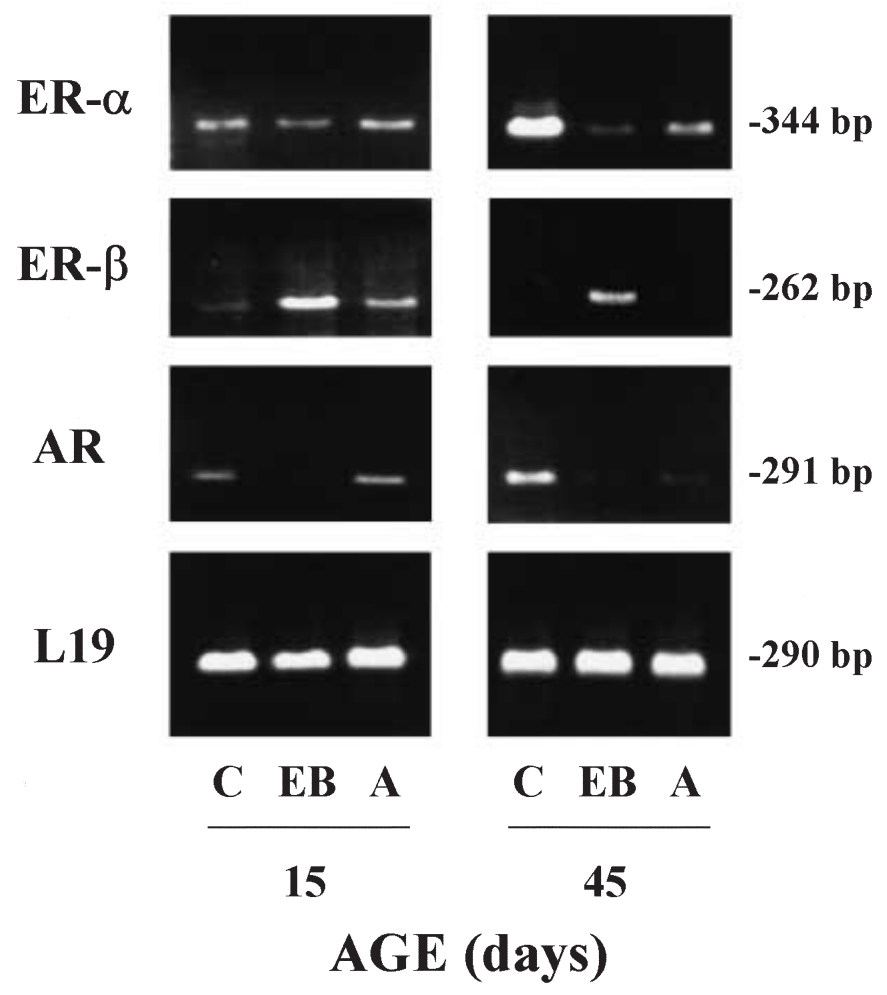

Figure 5 Representative ethidium bromide-stained gel electrophoresis of ER $\alpha$, ER $\beta$, AR and L19 cDNA fragments amplified by RT-PCR, from total testicular RNA samples of controls (C), neonatally estrogenized (EB) rats, and rats treated neonatally with LHRH-ANT (A). For comparison, two age-points are presented: day 15 ( $4 \mathrm{~h}$ after the last LHRH-ANT injection) and day 45 . The sizes of the generated products were calculated by comparison with the mobility of size markers (PCR 50-bp Step Ladder; data not shown), and are indicated on the right.

proven helpful in discriminating between direct actions and indirect effects of neonatal estrogenic compounds on the developing testis (Sharpe et al. 1998). Such an analysis revealed that the changes in testicular expression of ER $\alpha$, ER $\beta$ and AR messages were not solely attributable to estrogen-induced decrease in gonadotropin secretion during the critical period of neonatal differentiation, as relative levels of expression of $\mathrm{ER} \alpha, \mathrm{ER} \beta$ and $\mathrm{AR}$ mRNAs in 15-day-old rat testes were not significantly affected by LHRH-ANT treatment, and neither were those of ER $\beta$ in 45 -day-old rats neonatally treated with LHRH-ANT. Moreover, total expression per testis was significantly different between neonatally estrogenized and LHRH-ANT-treated groups for ER $\alpha$ (on day 45 of age), ER $\beta$ and AR (on days 15 and 45 of age) mRNAs. As a whole, our data suggest a direct action of estrogen on the developing testis and indicate divergences in the mechanisms for the effects of neonatal estrogenization on the morphological development of the testis and the pattern of expression of ER $\alpha$, ER $\beta$ and AR messages. On the former, previous experimental work has clearly demonstrated that estrogen-induced decrease in gonadotropin secretion during the neonatal period is the major cause for testicular atrophy in neonatally estrogenized rats (Bellido et al. 1990). Alternatively, as LHRH receptors have been identified in the neonatal rat testis (Huhtaniemi et al. 1984), we cannot rule out the possibility that, at least partially, the effects of neonatal administration of LHRHANT might be due to a direct action at the testicular level. However, the apparent limited relevance of locally produced LHRH in the control of testicular function (Huhtaniemi et al. 1987) casts doubts on such a possibility. Interpretation of the above results is simplified by previous references showing the pattern of gene expression and cellular distribution of $\mathrm{ER} \alpha, \mathrm{ER} \beta$ and AR within the developing rat testis. In this sense, it is well documented that expression of ER $\alpha$ is confined to Leydig cells (Fisher et al. 1997), whereas ER $\beta$ expression, at protein and mRNA levels, has been located to several types of germ cell (including gonocytes, type A spermatogonia, 
Relative Expression
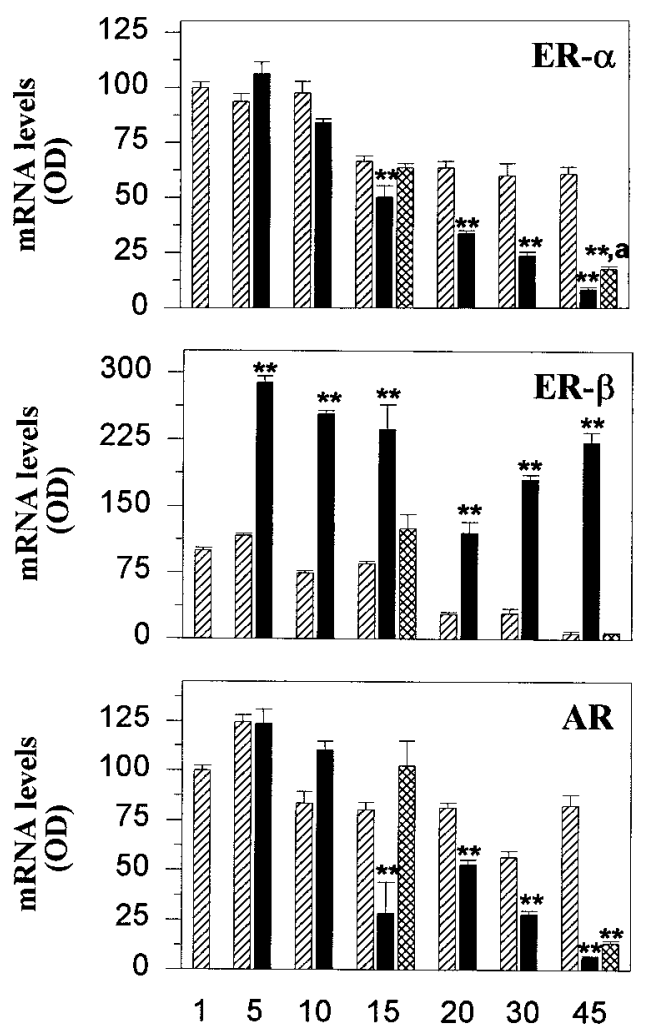

\section{Total Expression}
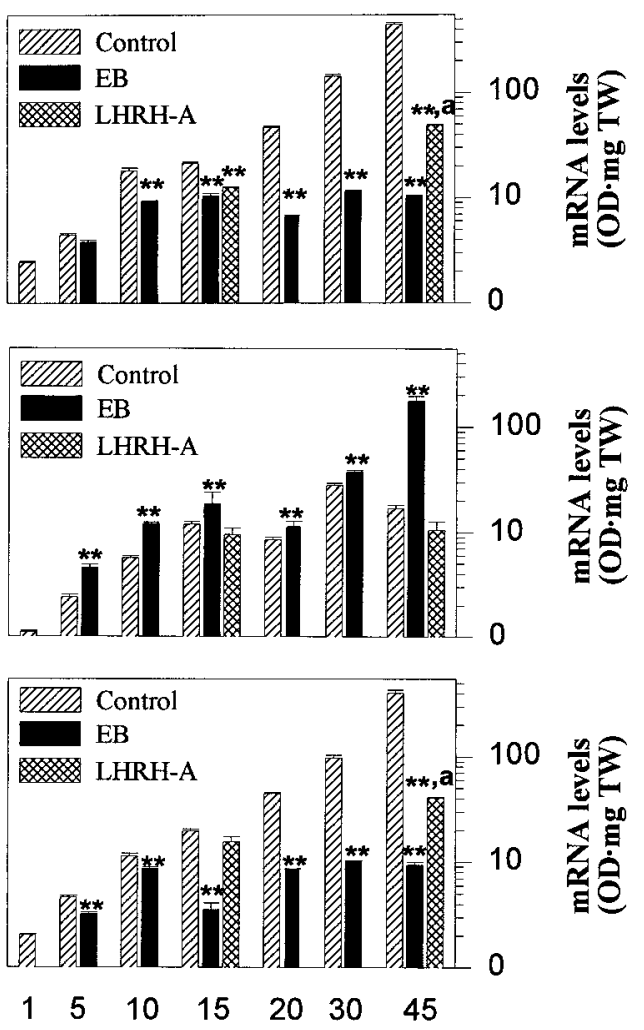

\section{AGE (days)}

Figure 6 Compilation of semi-quantitative data on the steady-state levels of ER $\alpha, E R \beta$ and AR mRNAs in testes from controls, neonatally estrogenized (EB) rats, and rats treated neonatally with LHRH-ANT (LHRH-A), at different time-points between the neonatal period (day 1 of age) and puberty (day 45 of age). Relative levels of expression were obtained, in each sample, by normalization of absolute ODs of each target (ER $\alpha, E R \beta$ and AR) with respect to that of the L19 signal, to express arbitrary units of relative abundance of the specific messages (left panels). Total levels of expression per testis were obtained after correction of relative values for testicular weight (OD.mg TW; right panels). Note that the latter values are plotted using semi-logarithmic presentation. Values are given as means \pm S.E.M. of at least three independent determinations. ${ }^{*} P<0 \cdot 01$ vs values from corresponding controls; $a=P<0 \cdot 01$ vs values from corresponding EB-injected groups (ANOVA followed by Tukey's test).

some pachytene spermatocytes and round spermatids) and Sertoli cells, as well as, at low levels, in fetal Leydig cells (Saunders et al. 1998, Van Pelt et al. 1999). In addition, prominent expression of AR has been identified in Sertoli cells during prepubertal development, a period when ARs are also abundant in peritubular myoid cells and interstitial cells (Bremner et al. 1995). On this basis, the decrease in the relative levels and total expression of ER $\alpha$ and AR mRNAs could be attributable, at least partially, to impaired development of testicular cell types expressing these genes after neonatal estrogenization (Gaytan \& Aguilar 1986, Gaytan et al. 1986, Pinilla et al. 1992). However, the increase in the expression of ER $\beta$ mRNA in this experimental model cannot be explained through alterations in the cellular composition of the testis, as it is well established that neonatal exposure to estrogen impairs/delays maturation of germ, Sertoli and Leydig cells within the developing male gonad (Gaytan \& Aguilar 1986, Gaytan et al. 1986, Pinilla et al. 1992). Furthermore, although alterations in cellular composition of testes (i.e. spermatogenic arrest with degenerating germ cells and delayed maturation of Sertoli and Leydig cells) are roughly similar between neonatally estrogenized and LHRHANT-treated male rats (Gaytan et al. 1986, Pinilla et al. 1994), striking differences were found in the pattern of response to these experimental manipulations in terms of 
ER $\beta$ mRNA expression, as significant increases in both relative levels and total mRNA expression were found only in estrogen-treated groups. Moreover, the possibility that the latter could be merely due to relative 'enrichment' of ER $\beta$ message after testicular shrinkage can be ruled out as neonatal estrogenization and LHRH-ANT treatment induced similar reduction in testis weight on day 15 of age (Fig. 1), yet only the former induces a significant increase in ER $\beta$ mRNA expression at this time-point. Taken together, our results strongly suggest that neonatal estrogen administration results in increased ER $\beta$ mRNA levels by acting directly on the developing testis. In addition, the possibility that changes in gonadotropin secretion after neonatal estrogen administration may contribute, at least partially, to its reported effects on ER $\alpha$ and $\beta$ mRNA expression cannot be completely excluded. In this scenario, identification of the pattern of cellular expression underlying the differential responses to neonatal estrogen administration in terms of ER $\alpha$ and ER $\beta$ mRNA levels will be our obvious next step.

In conclusion, the data presented herein demonstrate that neonatal exposure to estrogen differentially alters testicular expression of ER $\alpha$ and ER $\beta$ mRNAs during postnatal/prepubertal development. The mechanism for such a phenomenon is probably a direct action of estrogen on the developing testis, and is not attributable to estrogen-induced suppression of gonadotropin secretion during the neonatal period.

\section{Acknowledgements}

The authors thank Rocío Campón, Inmaculada Aguilar, Aila Metsävuori and Tarja Laiho for their skillful technical assistance. M T-S is indebted to Dr A Rannikko and Dr $\mathrm{P}$ Pakarinen for discussions and help during design and preparation of this manuscript. This work was supported by grants from DGICYT (Ministerio de Educación y Cultura, Spain) and project 1FD97-0696-02 (FEDER)

\section{References}

Abney TO \& Myers RB 1991 17ß-estradiol inhibition of Leydig cell regeneration in the ethylene dimethane sulfonate-treated mature rat. Journal of Andrology 12 295-304.

Aguilar E, Tejero A, Vaticón MD \& Fernández Galaz C 1984 Dissociation of luteinizing hormone and follicle-stimulating hormone control mechanisms in male and female rats by neonatal administration of estradiol benzoate or testosterone propionate. Hormone Research 19 106-116.

Arnold AP \& Gorski RA 1984 Gonadal steroid induction of structural sex differences in the central nervous system. Annual Review of Neuroscience 7 413-442.

Bellido C, Gaytan F, Aguilar R, Pinilla L \& Aguilar E 1985 Prepubertal reproductive defects in neonatal estrogenized male rats. Biology of Reproduction 33 381-387.

Bellido C, Pinilla L, Aguilar R, Gaytan F \& Aguilar E 1990 Possible role of changes in post-natal gonadotrophin concentrations on permanent impairment of the reproductive system in neonatally oestrogenized male rats. Journal of Reproduction and Fertility 90 369-374.

Bremner WJ, Millar MR, Sharpe RM \& Saunders PTK 1995 Immunohistochemical localization of androgen receptors in the rat testis: evidence for stage-dependent expression and regulation by androgens. Endocrinology 135 1227-1234.

Brinkmann AO, Leemborg FG, Roodnat EM, de Jong FH \& Van der Molen HJ 1980 A specific action of estradiol on enzymes involved in testicular steroidogenesis. Biology of Reproduction 23 801-809.

Brown-Grant K, Fink G, Greig F \& Murray MA 1975 Altered sexual development in male rats after oestrogen administration during the neonatal period. Journal of Reproduction and Fertility 44 25-42.

Chang C, Kokontis J \& Liao S 1988 Structural analysis of complementary DNA and amino acid sequences of human and rat androgen receptors. Proceedings of the National Academy of Sciences of the USA 85 7211-7215.

Chang X-L, Lin A, McNally J, Pelleg D, Meyuhas O \& Wool Y 1987 The primary structure of rat ribosomal protein L19. Journal of Biological Chemistry 262 1111-1115.

Chomczynski P \& Sacchi N 1987 Single-step method of RNA isolation by acid guanidinium thiocyanate-phenol-chloroform extraction. Analytical Biochemistry 162 156-159.

Eddy EM, Washburn TF, Bunch DO, Goulding EH, Gladen BC, Lubahn DB \& Korach KS 1996 Targeted disruption of the estrogen receptor gene in male mice causes alteration of spermatogenesis and infertility. Endocrinology 137 4796-4805.

Fisher JS, Millar MR, Majdic G, Saunders PTK, Fraser HM \& Sharpe RM 1997 Immunolocalisation of oestrogen receptor- $\alpha$ within the testis and excurrent ducts of the rat and marmoset monkey from perinatal life to adulthood. Journal of Endocrinology 153 485495.

Gaytan F \& Aguilar E 1986 Quantitative analysis of Sertoli cells in neonatally oestrogen-treated rats. Journal of Reproduction and Fertility 79 589-598.

Gaytan F, Pinilla L, Aguilar R, Lucena MC \& Paniagua R 1986 Effects of neonatal estrogen administration on the rat testis development with particular reference to Sertoli cells. Journal of Andrology 7 112-121.

Green S, Walter P, Kumar V, Krust A, Bornert J-M, Argos P \& Chambon P 1986 Human oestrogen receptor cDNA: sequence, expression and homology to v-erb-A. Nature 320 134-139.

Greene GL, Gilna P, Waterfield M, Baker A, Hort Y \& Shine J 1986 Sequence and expression of human estrogen receptor complementary DNA. Science 231 1150-1154.

Haavisto A-M, Pettersson K, Bergendahl M, Perheentupa A, Roser JF \& Huhtaniemi I 1993 A supersensitive immunofluorometric assay for rat luteinizing hormone. Endocrinology 132 1687-1691.

Hakola K, Haavisto A-M, Pierroz DD, Aebi A, Rannikko A, Kirjavainen T, Aubert ML \& Huhtaniemi I 1999 Recombinant forms of rat and human luteinizing hormone and follicle-stimulating hormone; comparison of functions in vitro and in vivo. Journal of Endocrinology 158 441-448.

Hess RA, Bunick D, Lee K-H, Bahr J, Taylor JA, Korach KS \& Lubahn DB 1997 A role for oestrogens in the male reproductive system. Nature 390 509-512.

Huhtaniemi IT, Clayton RN \& Catt KJ 1984 Gonadotropin-releasing hormone agonist analog-induced steroidogenic lesion in the neonatal rat testis: evidence for direct gonadal action. Endocrinology 115 233-238.

Huhtaniemi IT, Nevo N, Amsterdam A \& Naor Z 1986 Effect of postnatal treatment with a gonadotropin-releasing hormone antagonist on sexual maturation of male rats. Biology of Reproduction 35 501-507.

Huhtaniemi IT, Nikula H, Deta A, Stewart JM \& Clayton RN 1987 Blockade of rat testicular gonadotropin releasing hormone $(\mathrm{GnRH})$ receptors by infusion of a GnRH antagonist has no major effects on 
Leydig cell function in vivo. Molecular and Cellular Endocrinology 49 89-97.

Karolczak M \& Beyer C 1998 Developmental sex differences in estrogen receptor- $\beta$ mRNA expression in the mouse hypothalamus/preoptic region. Neuroendocrinology 68 229-234.

Kincl FA, Folch PA, Maqueo M, Herrera-Laso L, Oriol A \& Dorfman RI 1965 Inhibition of sexual development in male and female rats treated with various steroids at the age of five days. Acta Endocrinologica 49 193-206.

Koike S, Sakai M \& Muramatsu M 1987 Molecular cloning and characterization of rat estrogen receptor cDNA. Nucleic Acids Research 15 2499-2513.

Krege JH, Hodgin JB, Couse JF, Enmark E, Warner M, Mahler JF, Sar M, Korach KS, Gustafsson J \& Smithies O 1998 Generation and reproductive phenotypes of mice lacking estrogen receptor beta. Proceedings of the National Academy of Sciences of the USA 95 15677-15682.

Kuiper GGJM, Enmark E, Pelto-Huikko M, Nilsson S \& Gustafsson J-A 1996 Cloning of a novel estrogen receptor expressed in rat prostate and ovary. Proceedings of the National Academy of Sciences of the USA 93 5925-5930.

Kuiper GGJM, Carlsson B, Grandien K, Enmark E, Häggblad J, Nilsson S \& Gustafsson J-A 1997 Comparison of the ligand binding specificity and transcript tissue distribution of estrogen receptors $\alpha$ and $\beta$. Endocrinology 138 863-870.

Kuiper GGJM, Shughrue PJ, Merchenthaler I \& Gustafsson J-A 1998 The estrogen receptor $\beta$ subtype: a novel mediator of estrogen actions in neuroendocrine systems. Frontiers in Neuroendocrinology 19 253-286.

Kumar TR, Wang Y, Lu N \& Matzuk MM 1997 Follicle-stimulating hormone is required for ovarian follicular maturation but not male fertility. Nature Genetics 15 201-204.

MacLusky NJ \& Naftolin F 1981 Sexual differentiation of the central nervous system. Science 211 1294-1311.

Mitchner NA, Garlick C \& Ben-Jonathan N 1998 Cellular distribution and gene regulation of estrogen receptor $\alpha$ and $\beta$ in the rat pituitary gland. Endocrinology 139 3976-3983.

Naslund MJ \& Coffey DS 1986 The differential effects of neonatal androgen, estrogen and progesterone on adult rat prostate growth. Journal of Urology 136 1136-1140.

Newbold RR \& McLachlan JA 1985 Diethylstilbestrol associated defects in murine genital tract development. In Estrogens and the Environment II, pp 288-318. Ed JA McLachlan. New York: Elsevier.

Nilsson S, Kuiper G \& Gustafsson J-A 1998 ER $\beta$ : a novel estrogen receptor offers the potential for new drug development. Trends in Endocrinology and Metabolism 9 387-395.

Österlund M, Kuiper GGJM, Gustafsson J-A \& Hurd YL 1998 Differential distribution of estrogen receptor $\alpha$ and $\beta$ mRNA within the female rat brain. Molecular Brain Research 54 175-180.

Paech K, Webb P, Kuiper GGJM, Nilsson S, Gustafsson J-A, Kushner PJ \& Scanlan TS 1997 Differential ligand activation of estrogen receptors ER $\alpha$ and ER $\beta$ at AP1 sites. Science 277 1508-1510.

Pennie WD, Aldridge TC \& Brooks AN 1998 Differential activation by xenoestrogens of $E R \alpha$ and $E R \beta$ when linked to different response elements. Journal of Endocrinology 158 R11-R14.

Petersen DN, Tkalcevic GT, Koza-Taylor PH, Turi TG \& Brown TA 1998 Identification of estrogen receptor $\beta_{2}$, a functional variant of estrogen receptor $\beta$ expressed in normal rat tissues. Endocrinology 139 1082-1092.

Pinilla L, Garnelo P, Gaytan F \& Aguilar E 1992 Hypothalamicpituitary function in neonatally oestrogen-treated male rats. Journal of Endocrinology $134279-286$.

Pinilla L, Garnelo P, Tena-Sempere M, Gaytan F \& Aguilar E 1994 Mechanisms of reproductive deficiency in male rats treated neonatally with a gonadotropin-releasing hormone antagonist. Journal of Endocrinology 142 517-525.
Pinilla L, Tena-Sempere M, González D \& Aguilar E 1995 Mechanisms of altered LH secretion in neonatally oestrogenized male rats. Journal of Endocrinology 147 43-50.

Prins GS \& Birch L 1995 The developmental pattern of androgen receptor expression in the rat prostate lobes is altered after neonatal exposure to estrogen. Endocrinology 136 1303-1314.

Prins GS, Marmer M, Woodham C, Chang W, Kuiper G, Gustafsson J-A \& Birch L 1998 Estrogen receptor- $\beta$ messenger ribonucleic acid ontogeny in the prostate of normal and neonatally estrogenized rats. Endocrinology 139 874-883.

Pylkkanen L, Makela S, Valve E, Harkonen P, Toikkanen S \& Santti R 1993 Prostatic dysplasia associated with increased expression of c-myc in neonatally estrogenized mice. Journal of Andrology 149 1593-1601.

Robertson KM, O'Donell L, Jones ME, Meachem SJ, Boon WC, Fisher CR, Graves KH, McLachlan RI \& Simpson ER 1999 Impairment of spermatogenesis in mice lacking a functional aromatase (cyp19) gene. Proceedings of the National Academy of Sciences of the USA 96 7986-7991.

Santana P, Llanes L, Hernández I, González-Robayna I, Tabraue C, González-Reyes J, Quintana J, Estévez F, Ruiz de Galarreta CM \& Fanjul LF 1996 Interleukin-1 $\beta$ stimulates sphingomyelin hydrolysis in cultured granulosa cells: evidence for a regulatory role of ceramide on progesterone and prostaglandin biosynthesis. Endocrinology 137 2480-2489.

Sar M \& Welsch F 1999 Differential expression of estrogen receptor-beta and estrogen receptor-alpha in the rat ovary. Endocrinology 140 963-971.

Saunders PTK, Fisher JS, Sharpe RM \& Millar MR 1998 Expression of oestrogen receptor beta (ER $\beta$ ) occurs in multiple cell types, including some germ cells, in the rat testis. Journal of Endocrinology 156 R13-R17.

Shan L-X, Hardy DO, Catterall JF \& Hardy MP 1995 Effects of luteinizing hormone (LH) and androgen on steady state levels of messenger ribonucleic acid for $\mathrm{LH}$ receptors, androgen receptors, and steroidogenic enzymes in rat Leydig cell progenitors in vivo. Endocrinology 136 1686-1693.

Sharpe RM 1998 The roles of oestrogen in the male. Trends in Endocrinology and Metabolism 9 371-377.

Sharpe RM, Atanassova N, McKinnell C, Parte P, Turner KJ, Fisher JS, Kerr JB, Groome NP, MacPherson S, Millar MR \& Saunders PTK 1998 Abnormalities in functional development of the Sertoli cells in rats treated neonatally with diethylstilbestrol: a possible role for estrogens in Sertoli cell development. Biology of Reproduction 59 1084-1094.

Shughrue PJ, Lane MV \& Merchenthaler I 1997 Comparative distribution of estrogen receptor- $\alpha$ and $-\beta$ mRNA in the rat central nervous system. Journal of Comparative Neurology 388 $507-525$.

Tapanainen JS, Aittomäki K, Min J, Vaskivuo T \& Huhtaniemi I 1997 Men homozygous for an inactivating mutation of the follicle-stimulating hormone (FSH) receptor gene present variable suppression of spermatogenesis and fertility. Nature Genetics $\mathbf{1 5}$ 205-206.

Tena-Sempere M, Pinilla L \& Aguilar E 1993 Follicle-stimulating hormone and luteinizing hormone secretion in male rats orchidectomized or injected with ethylene dimethane sulfonate. Endocrinology 133 1173-1181.

Tena-Sempere M, Kero J, Rannikko A \& Huhtaniemi I 1999 Experimental cryptorchidism induces a change in the pattern of expression of luteinizing hormone receptor messenger ribonucleic acid in rat testis after selective Leydig cell destruction by ethylene dimethane sulfonate. Journal of Endocrinology 161 131-141.

Toppari J, Larsen JC, Christiansen P, Giwereman A, Grandjean P, Guillette LJ Jr, Jégou B, Jensen TK, Jouannet P, Keiding N, Leffers H, McLachlan JA, Meyer O, Müller J, Rajpert-de Meyts E, Scheike T, Sharpe RM, Sumpter JS \& Skakkebaek NE 1996 Male 
reproductive health and environmental xenooestrogens. Environmental Health Perspectives 104 741-803.

Tremblay GB, Tremblay A, Copeland NG, Gilbert DJ, Jenkins NA, Labrie F \& Giguere V 1997 Cloning, chromosomal localization and functional analysis of the murine estrogen receptor $\beta$. Molecular Endocrinology 11 353-365.

Van Pelt AM, de Rooij DG, Van der Burg B, Van der Saag PT, Gustafsson J-A \& Kuiper GG 1999 Ontogeny of estrogen receptor-beta expression in rat testis. Endocrinology 140 478-483.
Zheng X \& Hendry WJ III 1997 Neonatal diethylstilbestrol treatment alters the estrogen-regulated expression of both cell proliferation and apoptosis-related proto-oncogenes (c-jun. C-fos, c-myc, bax, bcl-2, and $\mathrm{bcl}-\mathrm{x}$ ) in the hamster uterus. Cell Growth and Differentiation 8 $425-434$.

Received 30 September 1999

Accepted 22 December 1999 